\title{
Development of Learning Solar System Augmented Reality for Elementary School
}

\author{
Agus Rineng Mattola* \\ Software Engineering Technology, \\ Agricultural Polytechnic of \\ Samarinda, Samarinda, Indonesia \\ agusrinengm25@gmail.com \\ *Corresponding Author
}

\author{
Reza Andrea \\ Software Engineering Technology, \\ Agricultural Polytechnic of \\ Samarinda, Samarinda, Indonesia \\ reza@bibirdesign.com
}

\author{
Budi Rachmadani \\ Software Engineering Technology, \\ Agricultural Polytechnic of Samarinda, \\ Samarinda, Indonesia \\ budi.rdani@gmail.com
}

Received: 2020-10-20; Revised: 2021-02-22; Accepted: 2021-02-26; Published: 2021-03-14

\begin{abstract}
Along with today's technological developments, applications can be used as a medium of learning. This study aims to create a learning application about the solar system by utilizing technology Augmented Reality which is expected to be used to support the Natural Science (IPA) learning program by an elementary school educational institution to make the teaching and learning system more creative and interactive. In this study, the method augmented reality used is Image Based Tracking, which uses images as markers. The tools that help in the making of this AR are the Vuforia SDK which is used as a storage area marker. By doing this research, the results obtained in the form of the Solar System Learning application Augmented Reality that runs on the platform Android and testing respondents using the method User Acceptance Testing (UAT)with a value of $73.5 \%$.
\end{abstract}

Keywords - Learning Applications, Augmented Reality, Image Based Tracking, UAT, Solar System, IPA.

\section{INTRODUCTION}

Along with technological developments, applications can be used as a medium for learning. One of the technologies used today as a medium for learning technology Augmented Reality. Augmented Reality is a technology that combines two-dimensional and or threedimensional virtual objects into a three-dimensional real environment and then projects these virtual objects in real time and simultaneously(cahyono, 2015). Its application can help facilitate students in terms of learning, because the objects displayed are in 3D which can be equipped with animated images and sound. This will certainly help students in learning as a teaching aid (Sartika, et al, 2016).

SD Negeri 012 Samarinda Seberang is an IT-based public elementary school located in Samarinda City, East Kalimantan Province, Indonesia. One of the goals of this school's IT-based is to facilitate the teaching and learning process, by utilizing existing technology, the easier it is for the school to achieve its goals, one of the subjects that requires aids to facilitate the learning process is Natural Science (IPA), therefore a teaching aid is needed that can facilitate and trigger interest in learning and Augmented
Reality technology is a technology that is expected to be a substitute for teaching aids that are not available to assist in the delivery of material in the Solar System (Rina, 2016).

Making this application is the use of technology Augmented Reality and games educational and the media is a smartphone. In this study, the method augmented reality used is Image Based Tracking, which utilizes images that have been made as markers. The tools that help in the making of this AR are the Vuforia SDK which is used as a storage area marker (Roedayan, 2016).

There are cases that are relevant to the research that will be made, in the journal Rosa, Agmita Clara, et al (2019) making learning media with technology augmented reality where the object used is also the sun and 8 other planets, but it is not explained that the application has other features such as the type of quiz, music or sound and object animation in the application, then the marker used is also qr code, while in the application that will be made the object will be animated or moving and the addition of sound and music in the application or the marker used is also an image so that students use it as well. can see a comparison of the original object image in 2D with 3D, accompanied by animation.

This application will later display Augmented Reality as its object and quizzes as a game. Apart from displaying and giving quizzes, the game also provides a score for each answer and an animated object. The objects in this application will be the Sun and 8 other planets taken from science textbooks. That way this application is intended for elementary school students (Andrea dkk, 2019).

\section{LITERATURE REVIEW}

\section{A. Study of literature}

Several studies are used as guidelines and references in making this application, among others.

Research conducted by Latius Hermawan and Mochamad (2015) entitled "The Utilization of Augmented Reality as Campus Information Media Using Brochures". This study aims to produce an android application that can display a 3D brochure model in an environment Augmented Reality so that it can help 
readers to know which campus to choose well (Hermawan, Hariadi, 2015). Augmented Reality technology.

In the journal Prihantoro Herlambang, (2015) entitled "Augmented Reality Edu game, the Life Cycle of Living Beings Based on Android". The purpose of this research is to make a learning game in order to attract students 'interest in learning and help teaching and learning activities for the 2013 curriculum. The benefit of this research is to help teachers become easier in teaching because with the addition of games and augmented reality to attract students' attention to be more focused on material and students can get to know better what games are educational, and can distinguish between games that are useful for education and those that are only harmful (Prihantoro, 2015).

RisYesn Arief SetYeswan, (2016) with the title "Analysis of the Use of the Method Marker Tracking Augmented Reality of Traditional Central Java Musical Instruments". The purpose of this research is to develop an AR application to display traditional musical instruments of Central Java Province in the form of simple 3dimensional animation, and its benefits are to facilitate the introduction of traditional Central Javanese musical instruments using AR technology (SetYeswan, 2016).

Yuni Sartika, (2016) entitled "Solar System Learning Applications for Ipa Grade 6 Elementary Schools Using Augmented Reality Android-Based". The purpose of this research is to build a Solar System Learning Application for Class 6 Elementary School Science Using Augmented Reality Based on Android, providing learning media facilities that contain descriptions of the circulation of planets in the solar system with animated images, describing the characteristics of the planets in the solar system. The benefit provided is that students can understand the material (Sartika, et al, 2016).

Agmita Clara Rosa, et al (2019) in a study entitled "Engineering Augmented Reality Planets in the Solar System as a Learning Media for Students of SMP Negeri 57 Palembang". The purpose of this research is to build a simulation system for the planet's solar system of the Milky Way as an interactive learning medium for students using technology augmented reality android- based which is effective in providing information about planet descriptions, planetary layers and can be used for learning, there are quiz questions in the application (Rosa et al, 2019). Comparison with previous research can be seen in Table 1.

Table 1. Comparison Table

\begin{tabular}{|l|l|l|l|}
\hline$\#$ & Name & Research Title & Information \\
\hline 1. & $\begin{array}{l}\text { Latius } \\
\text { Hermawan } \\
\text { and } \\
\text { Mochamad } \\
\text { Hariadi (2015) }\end{array}$ & $\begin{array}{l}\text { Utilization of } \\
\text { Augmented Reality as } \\
\text { Campus Information } \\
\text { Media Using Brochures }\end{array}$ & $\begin{array}{l}\text { This application } \\
\text { focuses on } \\
\text { helping people } \\
\text { get campus } \\
\text { information using } \\
\text { brochures with 3D } \\
\text { views. }\end{array}$ \\
\hline 2. & $\begin{array}{l}\text { Prihantoro } \\
\text { Herlamban g } \\
\text { (2015) }\end{array}$ & $\begin{array}{l}\text { Augmented Reality } \\
\text { Edugame Life Cycle of } \\
\text { Living Things Based on } \\
\text { Android }\end{array}$ & $\begin{array}{l}\text { This learning } \\
\text { application focuses } \\
\text { on learning content } \\
\text { that aims to } \\
\text { recognize the life } \\
\text { cycle of living } \\
\text { things in the } \\
\text { environment with }\end{array}$ \\
\hline
\end{tabular}

\begin{tabular}{|c|c|c|c|}
\hline & & & $\begin{array}{l}\text { Augmented Reality } \\
\text { technology. }\end{array}$ \\
\hline 3. & $\begin{array}{l}\text { RisYesn } \\
\text { Arief } \\
\text { SetYesw } \\
\text { an (2016) }\end{array}$ & $\begin{array}{l}\text { Analysis of the Use } \\
\text { of the Marker } \\
\text { Tracking Method in } \\
\text { the Augmented } \\
\text { Reality of } \\
\text { Traditional } \\
\text { Central Java Musical } \\
\text { Instruments }\end{array}$ & $\begin{array}{l}\text { The application } \\
\text { developed focuses on } \\
\text { the introduction of } \\
\text { traditional Central } \\
\text { Javanese musical } \\
\text { instruments with a } \\
\text { simple 3D view. }\end{array}$ \\
\hline 4. & $\begin{array}{l}\text { Yuni } \\
\text { Sartika, et } \\
\text { al (2016) }\end{array}$ & $\begin{array}{l}\text { Solar System } \\
\text { Learning Application } \\
\text { For Ipa Grade } 6 \\
\text { Elementary School } \\
\text { Using Augmented } \\
\text { Reality Based on } \\
\text { Android }\end{array}$ & $\begin{array}{l}\text { This application } \\
\text { focuses on the } \\
\text { features provided in } \\
\text { facilitating teachers } \\
\text { and students of SD } \\
\text { Sukabirus as an } \\
\text { alternative means of } \\
\text { learning and teaching. }\end{array}$ \\
\hline 5. & $\begin{array}{l}\text { Agmita } \\
\text { Clara Rosa, } \\
\text { et al (2019) }\end{array}$ & $\begin{array}{l}\text { Augmented Reality } \\
\text { Engineering Planets } \\
\text { in the Solar System } \\
\text { as Learning Media } \\
\text { for Students of SMP } \\
\text { Negeri } 57 \\
\text { Palembang }\end{array}$ & $\begin{array}{l}\text { This research focuses } \\
\text { on discussing the } \\
\text { description of the } \\
\text { planets, the content of } \\
\text { the atmospheric } \\
\text { elements that exist in } \\
\text { each planet. }\end{array}$ \\
\hline
\end{tabular}

\section{B. Development}

Siagian (1994) provides an understanding of development as "an effort or series of growth and change efforts that are planned and carried out consciously by a nation, state and government, towards modernity in the framework of nation building".

Ginanjar Kartasasmita (1994) provides a simpler definition, namely as "a process of change for the better through planned efforts".

From the above definitions, development can be interpreted as a process of change for the better based on goals planned, both from the aspects of society, politics, economy and technology (Mulyesdi, 2019).

\section{Application}

An application is a change from a problem or a job in the form of things that are difficult to understand to be simpler, easier and can be understood by users. So that with the application, a problem will be helped more quickly and precisely. Applications are also software that convert manual work to be more efficient with the help of computers (Randi, 2017).

Applications according to Dhanta, quoted from SanjaYes (2015), are software created by a computer company to do certain tasks, for example Microsoft Word, Microsoft Excel. Application comes from the word application which means application of application for use.

\section{Learning}

Learning is a complex activity. Learning is basically not just conveying messages but also an activity professional that requires teachers to use basic teaching skills in an integrated manner and create efficient situations (Mashudi, Toha et al, 2007). Therefore, in learning the teacher needs to create a conducive atmosphere and learning strategies that attract students' interest 


\section{E. Learning Application}

Learning applications are the media used in learning, which includes teaching aids in teaching and means of carrying messages from learning sources to teach message recipients (students). As a presenter and channel of messages, instructional media applications can in certain cases represent the teacher presenting learning information to students. If the learning application is well designed and developed, then that function can be played by the media even without the presence of a teacher. In general, the benefits of learning media applications are facilitating the interaction between teachers and students so that learning activities are more effective and efficient.

\section{F. Solar System}

Khamim, (2019). The (Solar System) consists of a star called the sun and all the objects that surround it. These objects include the eight planets known with orbits shaped ellipses, meteors, asteroids, comets, dwarf or dwarf planets, and natural satellites.

\section{G. Augmented Reality}

According to Prita HarYesni and Joko Triyono (2017). Augmented Reality (AR) is one part of the Virtual Environment (VE) or commonly known as Virtual Reality (VR). AR provides an overview to the user about the merging of the real world with the virtual world seen from the same place. AR has three characteristics, namely interactive (increasing user interaction and perceptions with the real world), according to real time and in the form of 3 dimensions, which is an amalgamation of the real world and the virtual world. Augmented Reality illustration can be seen in Picture 1.

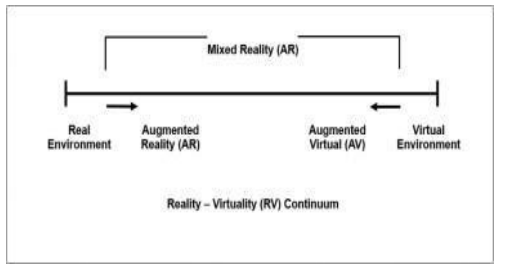

Picture 1. Illustration of Augmented Reality

Augmented Reality is a variation of Virtual Reality. The difference is that Virtual Reality is a technology that entirely engages the user in an artificial environment, but the user cannot see virtual objects in the real world environment. But Augmented Reality, on the other hand, can bring virtual objects in the artificial environment into the real world. Augmented Reality can bring up objects virtual in the real world at the same time. The virtual object is side by side with the real world. Augmented Reality requires a scanning tool to bring up objects. The process can be seen in Picture 2 .

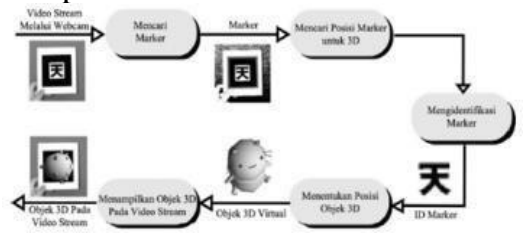

Picture 2. How Augmented Reality Works

\section{H. Multimedia}

According to Vaughan (2004) in Hermawan and Hariadi (2015) multimedia is a combination of text, art, sound images, animation, and video delivered by computer or digitally manipulated and can be delivered and / or controlled interactively. There are 3 types of multimedia are:

1. Interactive Multimedia

2. Hyperactive multimedia

3. Linear multimedia

An overview of the definition of multimedia can be seen in Picture 3.

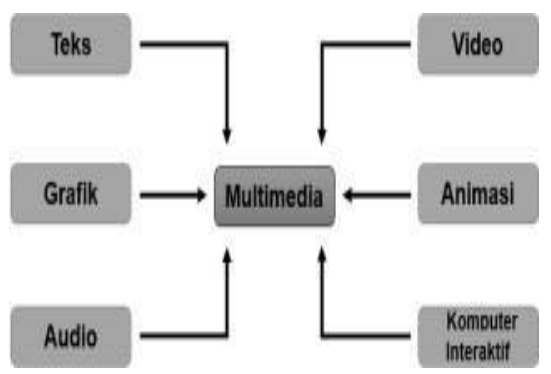

Picture 3. Multimedia Component

\section{Image Based Tracking}

According to Chari (2008). Augmented Reality marker is a type of Augmented Reality that recognizes markers and identifies patterns from markers to add object virtual to the real environment. Marker is an illustration of a black and white rectangle with thick black sides, a black pattern in the middle and a white background (Satria \& Prihandoko, 2018).

From the definition above, the Augmented Reality Marker can be described as shown in Picture 4.

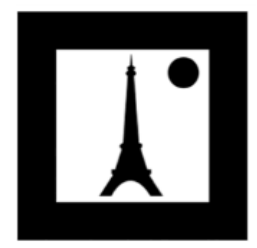

Picture 4. Marker Example

The Coordinate point virtual on the marker serves to determine the position of the object virtual that will be added to the real environment. The position of the object virtual will be perpendicular to the marker. The object virtual will stand in line with the $\mathrm{Z}$ axis and perpendicular to the $\mathrm{X}$ axis (right or left) of the $\mathrm{Y}$ axis (front or back) of the coordinates virtual marker. From the definition above, the coordinates of the Augmented Reality Marker can be described as shown in Picture 5.

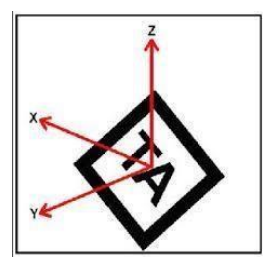

Picture 5. Point Coordinates on the Marker 


\section{J. User Acceptance Testing}

According to Perry (2006), User Acceptance Testing is a test carried out by an end-user where the user is a company staff or employee who directly interacts with the system and verifies whether the function is there has been running according to their needs or functions(Yousnelly dkk, 2015).

From the definition above, user acceptance testing is a test carried out by users of the system to ensure that the functions in the system are running well and in accordance with user needs.

\section{RESEARCH METHODS}

\section{A. Place And Time}

This research was conducted at the 012 Public Elementary School in Samarinda Seberang area (Felicia, 2013). When the research was conducted in the odd semester of the 2019-2020 school year, it was carried out for a period of approximately 6 (six) months, starting from September 2019 - March 2020 which consisted of preparing data information collection, application design and report preparation.

\section{B. Tools and Materials}

The tools used in this research include:

1. Hardware

1) Computer or laptop with processor $2.27 \mathrm{GHz}, 2.3 \mathrm{GHz}$

2) RAM 8 GB

3) VGA $1760 \mathrm{MB}$

4) smartphone Xiaomi Redmi Note 5 Plus with operating system Android

5) Mouse

6) Printer

2. Software

1) Windows 7 Operating System

2) Vuforia SDK

3) Unity $3 \mathrm{D}$

4) Blender

The materials used in this research include:

1. Science textbooks

2. Audio/ sound

\section{Research Procedure}

The stages of research that will be carried out in this study, with a sequential approach starting from conceptualizing, designing or designing, gathering material, composing and making, testing and distribution or the dissemination stage. The research stages can be seen in Picture 6.

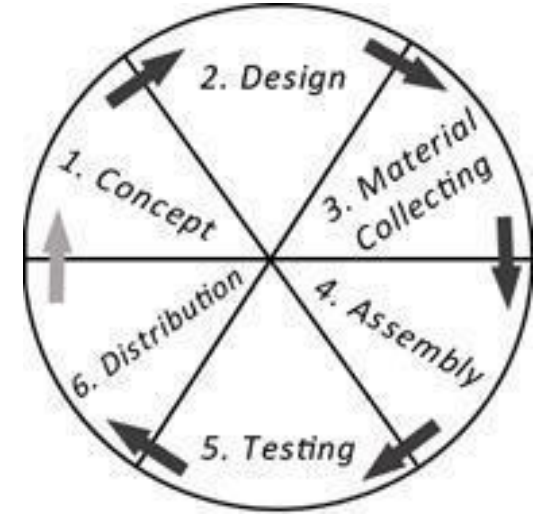

Picture 6. Multimedia Development Stages

1. Concept

In the initial stages used in building this application, two diagrams are used, namely, Use Case Diagrams and Activity Diagrams where in the Activity Diagram there are three Activities, namely, Starting AR, Quizzes and Instructions. The following is an overview and explanation of each concept:

1)Use Case Diagram

following is a Use Case Diagram of the application flow, starting when the user first runs the application. In the application system there are several main menus including Menu: About, instructions for use, scan markers, doing exercises and exiting the application, see Picture 7.

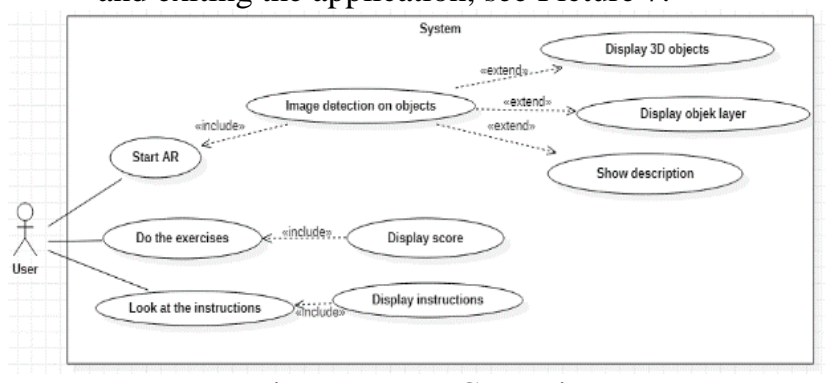

Picture 7. Use Case Diagram

2) Activity Diagram

Picture 8 is an activity diagram of the application Augmented Reality that was built (Fauzi \& Ramzogi, 2013) 


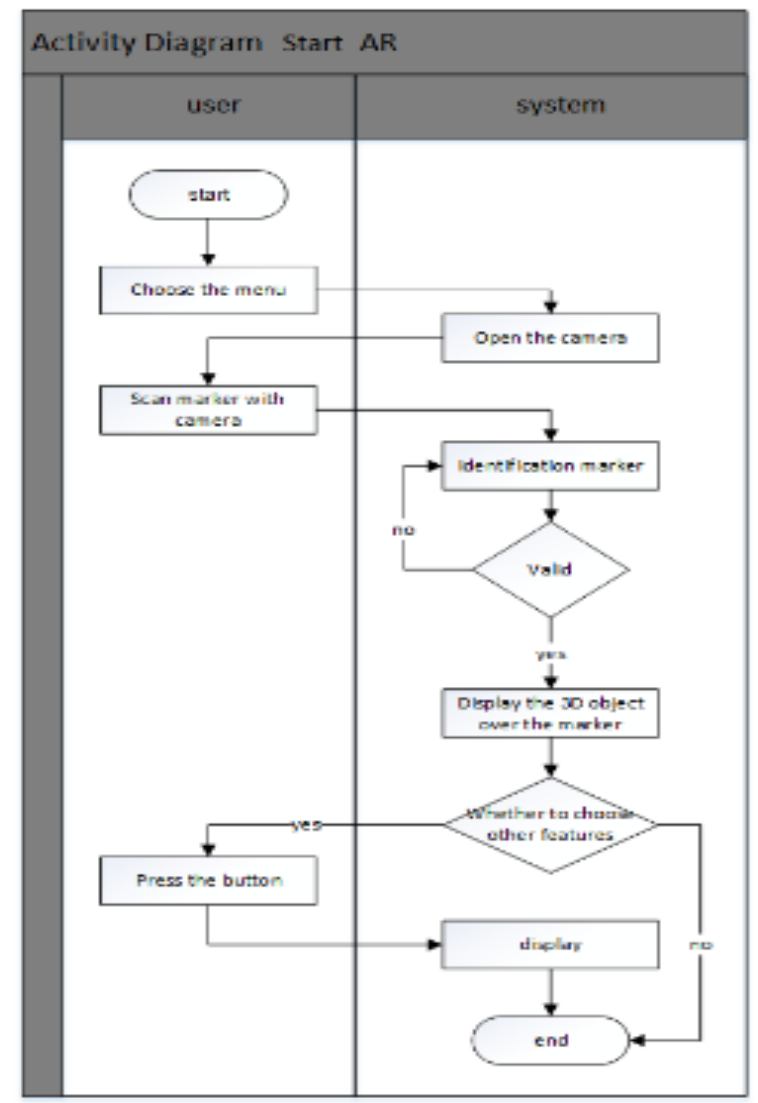

Picture 8. Activity Diagram

2. Design

Making the view interface of the application and making 3D objects from the planets (Kusuma, 2018).

3. Material Collecting

Material Collecting is the stage of collecting materials in accordance with the needs being done. These materials include textbooks, pictures or photos of planets, audios, etc. which can be obtained free of charge or by ordering from other parties according to the design. This stage can be done in parallel with the stage Assembly. However, in some cases, stage collecting material and phase of Assembly will be done in a linear and not parallel (Meilani, 2018).

4. Assembly

Phase Assembly is the stage of manufacture of all objects or multimedia materials. Making an application based on stage, design such as design interface (Tania, 2015).

5. Testing

Phase Testing (testing) is performed after completion of the manufacturing stage (Assembly) to run applications or programs and see if there is a mistake or not. The first stage at this stage is that the test is carried out by the manufacturer or the manufacturing environment itself. After testing is complete, testing involving the end use will be carried out. When the final test is carried out, the method used is the method User Acceptance Testing (UAT). User Acceptance Testing is a testing process carried out by users with the output of a test result document that can be used as evidence that the software has been received and has met the requested requirements (SetYeswan \& Dzikri, 2016).

\section{Distribution}

If the testing phase is successful, this application will be applied to users who will use the application (Sagita \& Rini, 2014).

\section{RESULTS AND DISCUSSION}

\section{A. Application Build Views}

In Picture 9 the application is built using the Android platform so that later the application can be installed and used on smartphones, especially those using the Android operating system.

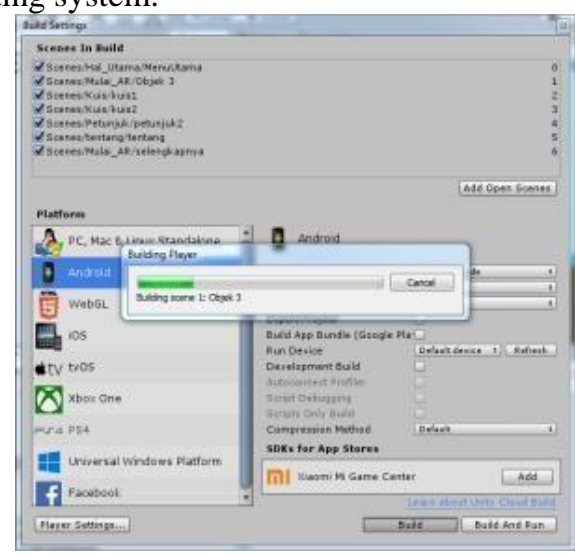

Picture 9. The process of building applications to the Android platform

\section{B. Display applications on a smartphone}

After the process is complete, the application is installed on the smartphone, then the application is run. In Picture 10 it is concluded that the application has been successfully installed on a smartphone and the application menu display is also responsive on the smartphone used.

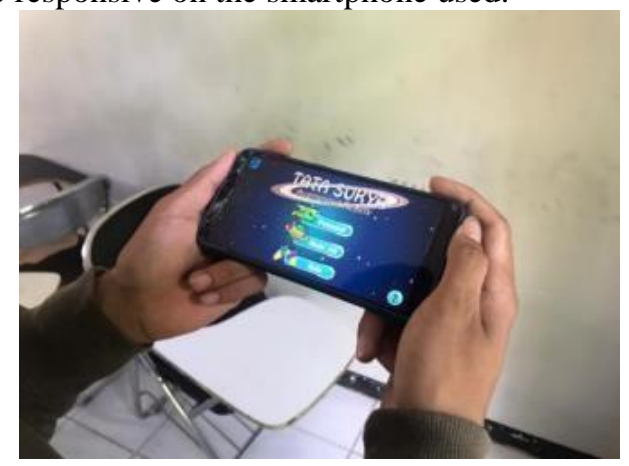

Picture 10. Main Menu Display on Smartphone

It is concluded that the instructions menu in Picture 11 is also responsive on the smartphone used be. 


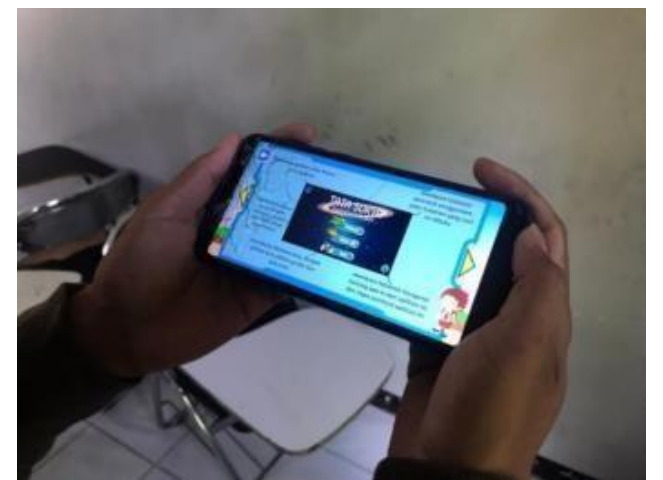

Picture 11. Display Guide Menu on Smartphone

It can be concluded that the AR Start menu in Picture 15 is also responsive on the smartphone and has successfully opened the camera and successfully carried out the tracking marker, in the process tracking marker there are also several steps to successfully bring up a $3 \mathrm{~d}$ object. The Process tracking on the marker will start from the image input stage, where the processor processes real time frames per frame from the captured user's image 12. The next step, namely the process image threshold can be seen in Picture 12, at each frame do this process until the image produces black and white. In the process of producing black and white, it aims to find out each shape and pattern of each frame captured image. The Process tracking is detecting markers which consists of 4 stages, namely contour extraction, corner detection, pattern normalization, and template matching.

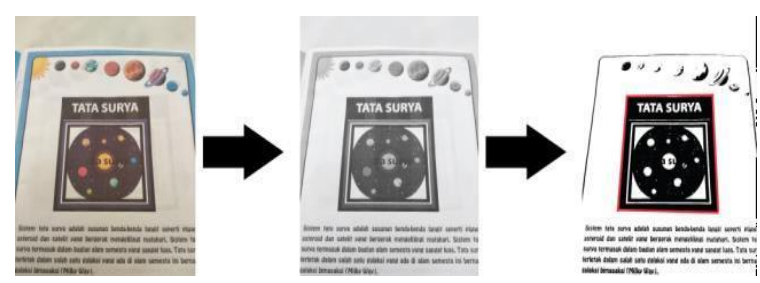

Picture 12. Image Threshold Stage

Contour extraction and corner detection process using black and white images obtained at the image threshold stage to get the coordinates. Picture 13 shows the next step, namely pattern normalization, which aims to make the marker in a normal position then the process template matching can be done correctly.

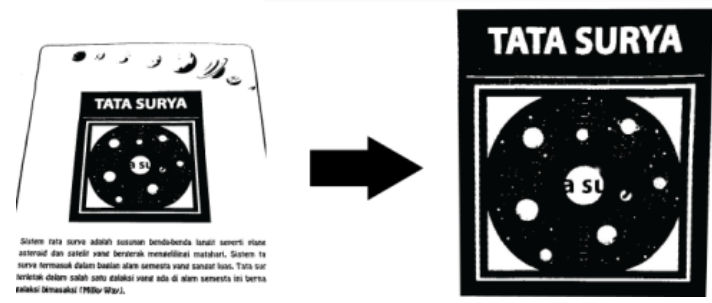

Picture 13. Pattern Normalization and Template Matching
The last stage is the relationship between the 3 coordinates, namely the $\mathrm{x}, \mathrm{y}$ and $\mathrm{z}$ coordinates, which can be seen in Picture 14 which plays an important role in which the $3 \mathrm{~d}$ object will be placed in the position of the object that has been adjusted before.

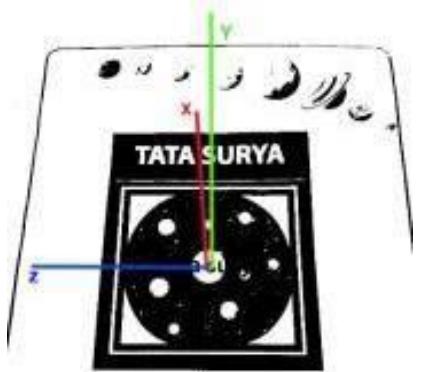

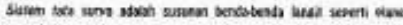

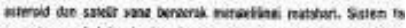

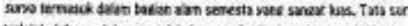

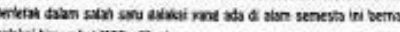

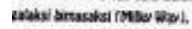

Picture 14. X, Y, and Z Coordinates

After that, the $3 \mathrm{~d}$ object will appear if the user points the camera at marker, in Picture 15 you can see the results on the smartphone screen when the user points the camera at the marker.

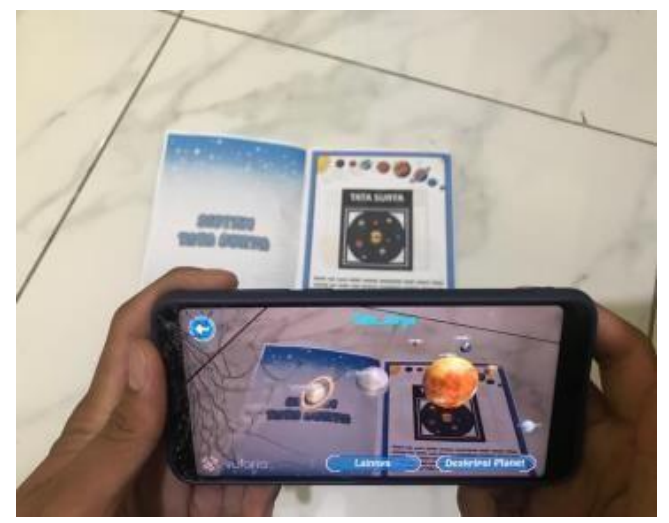

Picture 15. AR Start Menu Display on Smartphone

It can be concluded that the other menu in Picture 16 is also responsive on the smartphone used.

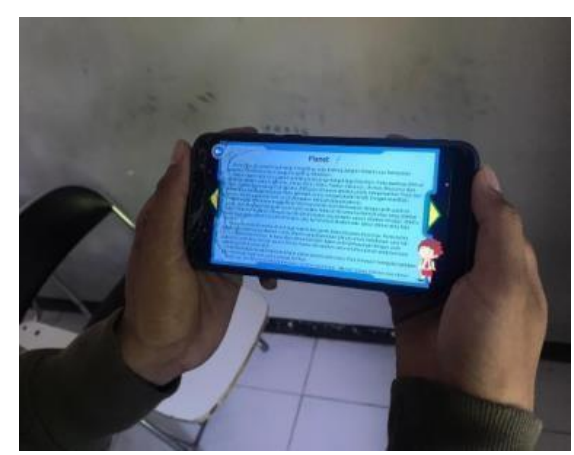

Picture 16. Other Menu Displays on Smartphone

The quiz menu in Picture 17 is also responsive on the smartphone used and the questions and answers have no problems. 


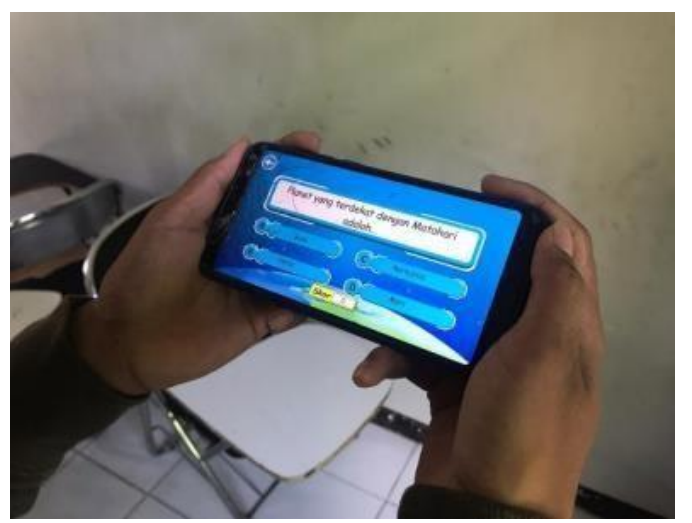

Picture 17. Display of the Quiz Menu on a Smartphone

It is concluded that the about menu in Picture 18 is also responsive on the smartphone used.

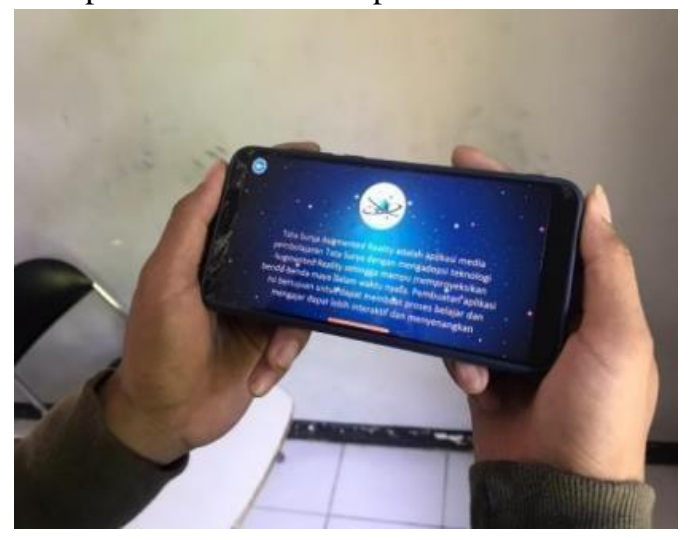

Picture 18. Menu Display About On Smartphone

In Picture 19 is a book used for applications, the book has been filled with a design from a marker

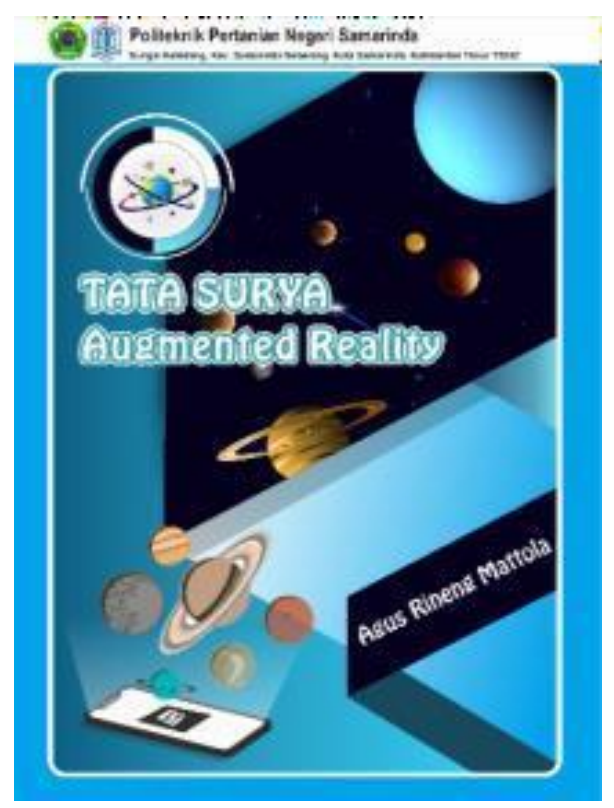

Picture 19. Augmented Reality Solar System Book

\section{Testing}

Testing this application consists of several tests, such as testing on smartphones, functionality and camera distance testing. After the application is finished, then application testing is carried out. In addition to functional testing, respondents also tested. Here are some of the tests performed.

\section{1) Testing on Smartphone}

Testing is carried out on 3 smartphones that have different specifications. Testing applications on several smartphones different aims to find out whether the application can run on each smartphone tested. The following is a list of smartphones used to test applications, see table 2 .

Table 2. List of Smartphone Testing Applications

\begin{tabular}{|c|c|}
\hline $\begin{array}{l}\text { Smartphone } \\
\text { Name }\end{array}$ & Specification \\
\hline $\begin{array}{l}\text { (S1) Xiaomi } \\
\text { Redmi } 5 \text { Plus }\end{array}$ & $\begin{array}{l}\text { Processor : Octa-core Max } 2.0 \mathrm{GHz} \\
\text { Cortex-A53 } \\
\text { Chipset : Qualcomm MSM8953 } \\
\text { Snapdragon } 625 . \\
\text { GPU : Andreno } 506 \\
\text { RAM : } 3.00 \mathrm{~GB} \\
\text { Rear Camera : } 12 \mathrm{MP} \\
\text { Screen Resolution : } 1080 \text { × } 2160 \text { pixels, } 18: 9 \\
\text { ratio } \\
\text { Android version : Android } 7.1 .2 \text { (nougat) }\end{array}$ \\
\hline $\begin{array}{c}\text { (S2) Samsung } \\
\text { Galaxy A30 }\end{array}$ & $\begin{array}{l}\text { Processor : Octa-core }(2 \times 1.8 \mathrm{GHz} \\
\text { Cortex-A73 \& 6x1.6 GHz Cortex- } \\
\text { A53) } \\
\text { Chipset : Exynos } 7904 \\
\text { GPU : Mali-G71 MP2 } \\
\text { RAM : } 4.00 \mathrm{~GB} \\
\text { Rear Camera : } 16 \mathrm{MP}, 5 \mathrm{MP} \\
\text { Screen Resolution: } 1080 \text { x } 2340 \text { pixels, 19.5:9 } \\
\text { ratio } \\
\text { Android version : Android } 10\end{array}$ \\
\hline $\begin{array}{l}\text { (S3) Y93 } \\
\text { Vivo }\end{array}$ & $\begin{array}{l}\text { Processor : Octa-core (4 x } 1.95 \text { dan } 4 \\
\text { x } 1.45 \text { GHz Cortex-A53) } \\
\text { Chipset : Qualcomm SDM439 } \\
\text { Snapdragon } 439 \\
\text { RAM : } 3 \text { GB } \\
\text { Rear Camera : } 13 \mathrm{MP}, 2 \mathrm{MP} \\
\text { Screen Resolution : } 720 \text { x } 1520 \text { pixels, 19:9 } \\
\text { ratio } \\
\text { Android version : Android } 8.1 \text { (Oreo) }\end{array}$ \\
\hline
\end{tabular}

2)Functional testing

The functional testing of this application aims to ensure that the software that has been made is as expected. See table 3 .

Table 3. Functional testing

\begin{tabular}{|c|l|l|}
\hline \multicolumn{2}{|c|}{ Table 3. Functional testing } \\
\hline Menu & \multicolumn{1}{|c|}{ Testing } & Information \\
\hline Main & $\begin{array}{l}\text { Displays the main page } \\
\text { of the Solar Augmented } \\
\text { Reality application }\end{array}$ & It works \\
\hline Hint menu & $\begin{array}{l}\text { Displays information } \\
\text { about instructions using the } \\
\text { Solar System AR app }\end{array}$ & It works \\
\hline $\begin{array}{c}\text { AR Start } \\
\text { Menu }\end{array}$ & $\begin{array}{l}\text { Displays 3D objects, } \\
\text { buttons and descriptions of } \\
\text { Solar System objects using the } \\
\text { Vuforiacamera }\end{array}$ & It works \\
\hline Other & $\begin{array}{l}\text { Displays other material } \\
\text { such as summaries and } \\
\text { mini dictionaries }\end{array}$ & It works \\
\hline Quiz Menu & $\begin{array}{l}\text { Displays a popup of quiz } \\
\text { choices to be played }\end{array}$ & It works \\
\hline
\end{tabular}


TEPIAN Vol. 2 No. 1 (March 2021) p-ISSN 2721-5350 e-ISSN 2721-5369

doi.org/10.51967/tepian.v2i1.208 @ 2021 TEPIAN Agricultural Polytechnic of Samarinda

\begin{tabular}{|l|l|l|}
\hline $\begin{array}{l}\text { Multiple } \\
\text { Choice Quiz } \\
\text { Menu }\end{array}$ & $\begin{array}{l}\text { Featuring multiple } \\
\text { choice quizzes }\end{array}$ & It works \\
\hline $\begin{array}{c}\text { Entry Quiz } \\
\text { Menu }\end{array}$ & Displays a quiz & It works \\
\hline $\begin{array}{c}\text { About } \\
\text { menu }\end{array}$ & $\begin{array}{l}\text { Displays information about } \\
\text { the application and developer }\end{array}$ & It works \\
\hline Exit Menu & $\begin{array}{l}\text { Displays a popup of } \\
\text { options for exiting the } \\
\text { application }\end{array}$ & It works \\
\hline
\end{tabular}

Next functional testing of smartphones that have been tested, this test aims to find out whether each smartphone used for testing can carry out each function in the application, both menu and features. Application features properly according to the expected results. The test results can be seen in table 4 .

Table 4. Functional Testing on Smartphone

\begin{tabular}{|c|c|c|c|c|}
\hline \multirow[t]{2}{*}{ Testing } & \multirow[t]{2}{*}{ Expected results } & \multicolumn{3}{|c|}{$\begin{array}{l}\text { Test results on a } \\
\text { smartphone } \\
\text { (successful) }\end{array}$} \\
\hline & & S1 & $\mathrm{S} 2$ & S3 \\
\hline Install the application & Application installed on smartphone & Yes & Yes & Yes \\
\hline Run the application & $\begin{array}{l}\text { The application runs } \\
\text { and displays the Main Menu page }\end{array}$ & Yes & Yes & Yes \\
\hline $\begin{array}{l}\text { Pressing the Menu button Help on the Main } \\
\text { Menu }\end{array}$ & $\begin{array}{l}\text { The application usage instructions page and the } \\
\text { download marker button will appear }\end{array}$ & Yes & Yes & Yes \\
\hline $\begin{array}{l}\text { Hit the Download Marker } \\
\text { button on the Other page }\end{array}$ & $\begin{array}{l}\text { A google drive page will appear containing marker } \\
\text { images for download }\end{array}$ & Yes & Yes & Yes \\
\hline $\begin{array}{l}\text { Pressing the AR Start menu button on the Main } \\
\text { Menu }\end{array}$ & $\begin{array}{l}\text { AR Start page display, on the AR Start page there is a More } \\
\text { button and when the marker is scanned a 3D object will appear, a } \\
\text { description button } \\
\text { and a planet data button }\end{array}$ & Yes & Yes & Yes \\
\hline $\begin{array}{l}\text { Pressing the Planet Description button on the AR } \\
\text { Start page display }\end{array}$ & $\begin{array}{l}\text { A description panel appears that contains a text description of the } \\
\text { object that appears and there is } \\
\text { a sound feature in the form of a button }\end{array}$ & Yes & Yes & Yes \\
\hline $\begin{array}{l}\text { Pressing the Sound feature button on the planet } \\
\text { description panel }\end{array}$ & Issued a narrative voice based on planet descriptions & Yes & Yes & Yes \\
\hline $\begin{array}{l}\text { Press the Planet Data button on the } \\
\text { AR Start page display }\end{array}$ & $\begin{array}{l}\text { The planet data panel appears, which contains text } \\
\text { in the form of planetary data }\end{array}$ & Yes & Yes & Yes \\
\hline $\begin{array}{l}\text { Pressing the More button on the AR Start page } \\
\text { display }\end{array}$ & $\begin{array}{l}\text { Another page appears that contains material in books that do not } \\
\text { have } 3 \mathrm{D} \text { objects and there are summaries and mini } \\
\text { dictionaries like in books }\end{array}$ & Yes & Yes & Yes \\
\hline $\begin{array}{l}\text { Pressing the Quiz menu } \\
\text { button on the Main Menu }\end{array}$ & The quiz selection popup will appear & Yes & Yes & Yes \\
\hline $\begin{array}{l}\text { Press the multiple choice button } \\
\text { on the popup display }\end{array}$ & The Multiple Choice Quiz page appears & Yes & Yes & Yes \\
\hline Press the Fill button on the popup display & The Fill Quiz page appears & Yes & Yes & Yes \\
\hline $\begin{array}{l}\text { Press the answer button on the Multiple Choice } \\
\text { and Fill Quiz page }\end{array}$ & $\begin{array}{l}\text { Provides output in the form of a score for the correct answer and } \\
\text { an animated notification of wrong or correct } \\
\text { answers }\end{array}$ & Yes & Yes & Yes \\
\hline $\begin{array}{l}\text { Pressing the About menu } \\
\text { button on the Main Menu }\end{array}$ & The application and developer page appears & Yes & Yes & Yes \\
\hline $\begin{array}{l}\text { Press the Exit } \\
\text { button on the Main Menu }\end{array}$ & $\begin{array}{l}\text { A popup appears } \\
\text { containing the Exit and Cancel buttons }\end{array}$ & Yes & Yes & Yes \\
\hline $\begin{array}{l}\text { Press the Exit } \\
\text { button on the Main Menu }\end{array}$ & $\begin{array}{l}\text { A popup appears } \\
\text { containing the Exit and Cancel buttons }\end{array}$ & Yes & Yes & Yes \\
\hline Press the Exit button on the popup display & Application stops running & Yes & Yes & Yes \\
\hline Hit the Cancel button on the popup display & Main Menu page appears & Yes & Yes & Yes \\
\hline
\end{tabular}




\section{Testing camera distance}

The next test is to test the input and output of the application, especially the camera Vuforia, the input on the camera is a marker, while the output is a $3 \mathrm{D}$ object and description or other features. The test conducted consists of testing the camera distance. The test results can be seen in table 5 .

Table 5. Camera Distance Testing

\begin{tabular}{|c|c|c|c|c|}
\hline No & $\begin{array}{c}\text { Camera } \\
\text { Distance }\end{array}$ & $\begin{array}{c}\text { Xiaomi } \\
\text { Red,I 5+ }\end{array}$ & $\begin{array}{c}\text { Succeed } \\
\text { Samsung Galaxy } \\
\text { A30 }\end{array}$ & Vivo Y39 \\
\hline 1 & $5 \mathrm{~cm}$ & No & No & No \\
\hline 2 & $10 \mathrm{~cm}$ & Yes & Yes & Yes \\
\hline 3 & $20 \mathrm{~cm}$ & Yes & Yes & Yes \\
\hline 4 & $30 \mathrm{~cm}$ & Yes & Yes & Yes \\
\hline 5 & $40 \mathrm{~cm}$ & Yes & Yes & Yes \\
\hline 6 & $50 \mathrm{~cm}$ & Yes & Yes & Yes \\
\hline 7 & $60 \mathrm{~cm}$ & Yes & Yes & Yes \\
\hline
\end{tabular}

In the table 5, it is concluded that the three smartphones used at a distance of $5 \mathrm{~cm}$ the $3 \mathrm{D}$ object cannot be read, while at a distance of $10 \mathrm{~cm}$ to $60 \mathrm{~cm}$ all devices can display the object. Weight of the value obtained in the questionnaire results will be included in the percentage formula that will be used to calculate the percentage obtained from the test.

The percentage obtained from the results of calculations using the formula above will be adjusted to the predetermined assessment standards, so that a conclusion can be drawn whether the application has been well accepted or not.

The questionnaire consisted of several questions and was given to science subject teachers and grade VI students at SD Negeri 012 Samarinda Seberang. Based on the results of the questionnaire above, it is known that this application is already running well. The value obtained from the UAT test on teachers and students is as follows.

$\begin{array}{ll}\text { Very Good (SB) } & 53 \\ \text { Good (B) } & 41 \\ \text { Enough }(\mathrm{C}) & 6 \\ \text { Bad }(\mathrm{J}) & 0 \\ \text { Very Bad (SJ) } & 0\end{array}$

After getting the results from the questionnaire, the following calculation results are obtained. (1)

$$
\begin{aligned}
\text { Test result }= & \frac{(2 \times 53)+[(1 \times 4])+(0 \times 6)+(-1 \times 0)+(-2 \times 0)}{10 \times 10} \times 100 \% \\
& =\frac{1478}{200} \times 100 \% \\
& =73.5 \%
\end{aligned}
$$

Based on the calculation results using the formula the percentage above, it can be concluded that the results of the UAT on the application have been very good.

\section{CONCLUSION}

Successfully built applications by applying technology augmented reality using the Unity game engine and Vuforia SDK which displays visualization of the solar system in the form of objects in 3D animation. Applications are also made to have a feature that displays a description of the planets and plays audio narration. The application also provides educational game features to practice questions about the solar system. It is hoped that it can help students understand the material given.

Applications can be props and also as an alternative media to help learn material about the solar system which is used as a teaching aid for teachers and students of SDN 012 Samarinda Seberang using technology Augmented Reality with the method Image Based Tracking.

Based on the responses of respondents in grade VI SD Negeri 012 Samarinda Seberang, they obtained an overall score of $73.5 \%$.

This application can only run on one platform, namely Android. This weakness is a reference so that it can be developed again so that it can be used on several platforms such as Windows Phone and iOS.

Addition of celestial objects, such as comets, meteors, constellations, etc.

Material in the application is only added during application creation, namely through software used, it is hoped that in the next development there will be features to add data about the material of the solar system directly in the application.

Thus the suggestions that the author can give, hopefully these suggestions can be used as input that can be useful for authors in particular and as reference material for developers in general.

\section{REFERENCES}

Andrea R., L. Siti, A. Fahrul, Ramadiani. 2019. "Magic Boosed" an elementary school geometry textbook with marker-based augmented reality. University Ahmad Dahlan.1242-1249.

Randi, A. 2017. "The Use of Virtual Reality Technology as an Interactive Learning Media for the Android-Based SurYes System". Published. Faculty of Science and Technology. Alauddin State Islamic University. Makassar.

Felicia, P. 2013. Getting Started With Unity. Packt Publishing.

Herlambang, P. 2015. "Edugame Augmented Reality Cycle of Living Things Based on Android". Published. Faculty of Communication and Informatics. MuhammadiYesh University. Surakarta.

Fauzi, H, and Ramzogi, O. 2013. "The Community Response at the Village Development Stage in Purbolinggo District, East Lampung Regency. (Case study on the PNPM MD Village Independent Community Empowerment Program) ". Faculty of Economics, University of Lampung. Lampung.

Khamim. 2019. Exploring Tata SurYes. Sukoharjo: Graha Printama Harmonious.

Kusuma, S. D. 2018. "Designing an Augmented Reality Application for SurYes Learning Using Marker Based Tracking". Pamulang University Journal of Informatics, 33-38.

Meilani, G. R. 2018. Building Augmented Reality Applications With Unity. Garuda Mas Sejahtera.

MulYesdi, D. 2019. My Creations The Tata SurYes Series. 
Tangerang: Loka Aksara. Cahyono, S, P. 2015. "Development of Interactive Learning Media to Improve Student Learning Outcomes in Class Viii at SMP Negeri 7 Semarang". Ekp, 1576-1580.

Rina, W. 2016. "Use of Contextual Teaching and Learning Learning Models to Improve Self-SelfConfidence Attitudes and Student Learning Outcomes on Diversity of Natural Appearances in Social Studies Learning". Published. Faculty of Teacher Training and Education. Pasundan University. Bandung.

Roedavan. 2016. Unity Game Engine Tutorial. Bandung: Informatics.

Rosa, A. C. 2019. "RekaYessa Augmented Reality Planet in SurYes System as a Learning Media for Students of SMP Negeri 57 Palembang". Scientific Journal of Informatics.

Tania, D. B. 2015. "Learning Application Let's Get to Know Time as Alternative Learning for First Grade Children of Elementary School". Published. Faculty of Engineering. WidYestama University. Bandung.

Sagita, S. M, and A. Rini. 2014. "Learning SurYes System Using Augmented Reality Technology". The Exacta Factor, 224-235.

Satria, B., and Prihandoko. 2018. "Assembly of the Marker Based Tracking Method in the Application of Build Space Based on Augmented Reality". Amikom YogYeskarta University, 1-5.

SetYeswan, R. A., and Dzikri, A. 2016. "Analysis of the Use of the Marker Tracking Method in Augmented Reality of Traditional Central Javanese Musical Instruments". Batam State Polytechnic. Batam.

Yousnelly. P, Saktyowati. D. O, Parulian. 2015. Enjoyed Learning Science. Yudhistira.

Sartika. Y, Telnoni, P, A, and Tambunan, T. D. 2016. "The Application of SurYes Learning for Science in Grade 6 Elementary Schools Using Augemented Reality Based on Android". E-Proceeding Of Applied Science, 895.

Hermawan and Mochamad. 2015. "Using Augmented Reality as Information Media." National Seminar on Information and Communication Technology 2015 $1-8$ 